\title{
The Effectiveness of Public Broadcasting Program Mimbar Agama Islamat Television of Indonesia Republic in Improving the Ability of Audience'sMedia Literacy in North Sumatra, Medan, Indonesia
}

\author{
Zulkifli \\ Ph.D Student at State University of North Sumatra (UINSU), Medan, Indonesia \\ Staff at Television of Indonesia Republic (TVRI), Medan, Indonesia
}

\begin{abstract}
Television is the result of an audio visual culture has managed to attract people to watch, at least television also affects the shaping the community's attitudes and personalities at large. This is due to the ability of television to reach the audiences with a large area. Television now seems to be the eyes and the voice of the audience, because between the television with the audience they have become an integral entity.Media literacy is multi dimensional. There are four important points between the dimensions of media literacy: the cognitive dimension, the emotional dimension, the dimension of beauty, and the moral dimension. The cognitive domain refers to mental processes and thinking.The effectiveness of the Public Broadcasting Television's Mimbar Agama Islam of Republic of Indonesia of North Sumatera in improving the media literacy ability of the viewers in Medan City. The effect of television media can be interpreted as a difference that occurs in a person before and after receiving the information from the television, whether it occurs in the volume of knowledge, new attitudes, or new behavior.
\end{abstract}

Keywords: public broadcasting; Mimbar Agama Islam; television; media literacy

\section{INTRODUCTION}

Television is a big business in the present century that is why in recent years there are many national and local private television broadcasting stations growing like mushrooms in the rainy season. For Indonesian people this is not surprising after so long Television of Republic of Indonesia (TVRI) served as a the only television broadcasting in Indonesia that displayed information or news, education, and entertainment for the people of Indonesia. With the presence of televisions managed by the private sectors is expected to provide a new brighter color in their formats and programs. It is not too difficult to be able to tie the heart of publicviewers and lead them to the presence of private broadcasting television.

If viewing from the history of television in Indonesia, then it appears that the economical and political structures of the New Order directly affect the change of the Indonesian press from the political press to industrial press. Meanwhile in Soekarno'sera the press was defined as an instrument of revolution to arouse public opinion so that most of the press would base its editorial policy with certain political segments. In Suharto's era, with the exception of some newspapers, most media aimed to reach a wide, cross-cultural, cultural, and political audience, in an effort to gain a wide circulation and attract the advertisers.

It is similar with broadcasting or television broadcasting in Indonesia. From the dozens of private television stations broadcasting nationwide by imprinted impressions displayed on the screen, they generally compete to reach as many audiences, or in other term the broadcastsdisplayed are generally to reach as many viewers as possible, without paying attention to the quality of the contents. Public Broadcasting Institution (LPP) of TVRI is one of the national electronic mass media institutions that first stood in Indonesia and began its broadcasting on August 24, 1962. In the early stages of TVRI until around the 1990s this broadcasting institution had no other competitors. The facts show that, as a single electronic audio visual media in the country at that time caused the mass media of TVRI became the propaganda tool of the ruler'spolitical interest that is the New Order government.

Since the birth of national private televisions in Indonesia, which currently there are 15 (fifteen) stations and dozens of local television stations, if viewing the packaging of the show, including the Islamic $d a^{\prime} w a h$ program, there is no escape from the effort to capture the audience as much as possible and not separated from the commercials advertisement displays Generally the private televisionseither national and local ones air the event that paid less attention to the four functions of balanced mass media, namely informing, educating, entertaining and social control. But ironically, television in the country today is merely pursuing the rating or share the audience alone. The conditions are worsened by the low ability of media literacy or the ability to select 
and to sort the contents of television broadcasts watched by the public in the country. Some communication theories that reveal the ability of the audience to choose and to sort the contents of television broadcasts, among others are proposed through the theory of uses and gratification. The interests of television managers broadcasting the less educate materials to the people and its impact has been disclosed from some research results which are quite relevant with the accurate proving.

The study results state that how strong the influence of television broadcasts in shaping the character and mental community including the Muslim community. Therefore, besides the role of teachers in schools, and parents at home, another potential role in educating people everywhere today is the television broadcasting. This is in accordance with the opinion of a communications expert BurhanBungin in his book SosiologiKomunikasiwhich states, the mass media has a very strong effect, especially because this assumption is related to the learning process and not with changes in attitudes and opinions.

According to observations on religion broadcasting programs on three television stations, SCTV, RCTI, and Indosiar, show that religion broadcasting programs on television are very few. The average is only about once broadcasting for a day, in broadcast duration just 30 minutes from an average of 23 hours of daily television broadcasts. It also includes advertisements that spend a third to half of the total time of religion broadcasts. So the effective Islamic religion broadcast is 15-20 minutes a day. The oldest age group who watch the religion broadcasts on television is 46 years of age or older. The averages of $62.07 \%$ of them watch religion broadcasts on television for more than 30 minutes a day. While the age group of 21-45 years who watch religion broadcast on television for more than 30 minutes is only about $25.58 \%$.

The results of this study also found that in general the people of Medan City included in heavy viewers of television, because they watch television just for 2-3 hours a day. Each week means they watch television for 14-21 hours. However, about $16.4 \%$ of them do not watch religions broadcasts and only about $34.5 \%$ who watch religions broadcasts for about 30 minutes per day. Others do not watch the entire religion broadcast until it is closed, because religion broadcasts are on air for 30 minutes for once broadcast.

Thus, the effects of media are still in viewed from a perspective type and have not been assessed in relation to the objectives, that is knowing who does what, for whom with what purpose. The different side of this study with previous research is focusing on the effectiveness of audience dialogue in the broadcast of Mimbar Agama Islamthat in this case of course the aims for syiarof Islamic da'wah. So the program of Mimbar Agama Islamheld by the Public Television Broadcasting Institution of the Republic of Indonesia is an Islamic $d a$ 'wah program that is packaged in a dialogical between the speakers with the audience or the listener. But the freedom of the media, which until now in Indonesia, still has not been able to create the rationality of most Indonesians. The freedom of the media actually perpetuates traditional and modern rationality, as Immanuel Kant and Hegel.F Budi Hardiman explain in the article "Theory of Discourse and Democracy, the Habermas's Transition into Political Philosophy" that the practical rationality of Kant's Philosophy refers to individual autonomy, that is to the universal nature or independent on particular social and historical contexts. The individual's subjective ability is identical with the subjective ability of a nation.

Since the enactment of Press Law number 32 year 2002 which the contents among others are regulating the obligation of network television broadcasting in Indonesia, in fact in the field until now the broadcast television network has not been fully implemented by the national private televisions. The implication is that many television impressions are centralized, and the commercial advertisement content messages enter the public space of the viewers in the regions level one in Indonesiaincluding North Sumatra.

If it is reviewed legally with the enactment of Press Law year 2002, the local public's right to receive the local information has not been fulfilled. Similarly, the da'wah shows, such as "CurhatBersamaMama Dedeh" now changed the title to "Mama and AaBeraksi" and others on national private televisionsare centralistic and commercial shows. Apparantlythrough broadcasting the da'wahcontent of national private television, the Indonesian society including in North Sumatra do not get $d a$ 'wah service with local speakers and do not accommodate the role of viewers to participate interactively in the broadcasting program. In fact, the government in President Gusdur 1998 era has opened a press as an effort of reform era to give freedom of media and open a space of public communication.

The communicative role of the society must be grown because the communicative action is the critical attitude of the society to think critically on the realities of socio-cultural and politics, as an effort to create economic or individual reflection and dare to claim their claims as discourse to consensus. One of the critical attitudes that must grow in society is the emancipator's attitude that is the equal participation of each individual member of society to dare to claim their validity in communicating. The communicative role of society needs to be developed so that the rationality of thinking is also honed. JurgenHabermas explains that, rationality is the core of communicative human. Rationality creates intersubjective and human autonomy in thinking and acting, as well as being able to develop discourse toward communicative society beginning with human rationality, that is, the ability of human's mind in thinking, creating reality in discourse and producing consensus for human interest. The supreme mind of human is the mind that holds the head of the human mind reality. The mind and 
the ability of human thinking give a higher function that is human needs to education, self-actualization, socialization, creating rules, system, norm, and culture as well as civilization.

\section{METHODOLOGY}

Recently, one of the most popular ways to see the effect of communication is using the effect of "usability and satisfaction". The opinion of Swanson (1979) on the basic idea behind this effect is that the audience is active in utilizing the mass media. Individuals do not spontaneously and automatically respond to the mass media messages such as those expressed in the effects of bullets or hypodermic needles (audience is considered passive).In other words, individuals use the content of the media to fulfill their purpose in the effort to enjoy the mass media. These purposes will be matched to the needs and desires of each individual. If needs are met through mass communication channels, means the individual achieves a level of satisfaction. ${ }^{1}$ According to John R. Bittner (1996), the main focus of this effect is not only how the media affect the audience, but also how the audience reacts to the media messages that arrive. The interaction factors that occur between the individuals will influence the message received. This is clearly contrary to the assumption of the effects of bullets or hypodermic needles. All can be framed with questions not only, "What do the media do to the audience?" but also more importantly is "What does the audience do in the media?"

According to Potter (2005) the definition of media literacy is a collection of perspectives in which we actively reveal ourselves to the media to interpret the meaning of the messages we receive. We build our perspective from the structure of knowledge. Building the structure of our knowledge requires tools and basic materials. These tools are our skills. The raw material is any information from the media and from the real world. Activeto use the media aims that we are aware of the messages and quickly interact with them.

Media literacy is multi dimensional. There are four important points between the dimensions of media literacy: the cognitive dimension, the emotional dimension, the dimension of beauty, and the moral dimension. The cognitive domain refers to mental processes and thinking.

The cognitive ability refers to the level of consciousnessfrom simple symbols to a complex understanding of how a message is produced and why it is delivered in that way. This is the intellectual dimension. The reality lies on the power of knowledge structures to give many contexts in the meaning constructions. The emotional domain is the dimension of feeling. Some people are less sensitive and difficult to arouse their emotions when they pose themselves to the media, others are very sensitive and easily evoked their emotions when they are hit by the mass media.

Since the Indonesian government released TVRI, then for 27 years the television viewers in Indonesia could only watch one television channel. Then in 1989 the government granted an operating license to Bimantara business group to open RCTI television station which was the first private television in Indonesia, followed by SCTV, Indosiar, ANTV and TPI. Since 2000 there have been almost simultaneously five new private Televisions, Metro Trans, TV-7, Lativi and Global.After the Law of Broadcasting was passed in 2002, the number of new televisions in Indonesia is expected to emerge continuously, especially in the region, which is divided into four categories: public, private, subscription and community. Now Indonesian television viewers really have many options to enjoy various television programs. The description of the media function so far is generally focused on the positive things, but behind it actually there are also negative things which sometimes do not appear in the Media workprocess, that is to change or hide the dual purposes of mass media as advertiser media of real economic service product. In addition, perhaps as a media capability there is also an insurmountable negative consequence, that is the latent elements and dysfunctional elements as Wright (1960)mentioned, although they are essentially still hypothetical. The mass media analysts do recognize that media can basically be similar to a double-edged knife, on the one side the media can provide a positive function that are useful for human life, while on the other side the media can also provide a negative function that can change the social, economic, and political order of the society.

One of the relevant opinions is the reality that television is the medium for advertisers. In Indonesia television media is an intensive industrycapital, solid technology and human resources. But unfortunately the emergence of various television stations in Indonesia is not balanced with the availability of adequate human resources. In general, television is established without adequate television knowledge it is only based on the spirit and large capital only. For that reason, to make the viewers are not just the targets of the television owners, especially the private national television in Indonesia it is important to have the ability of media literacy. Literacy initially is related to literal, where people who are able to read and write which are termed as literacy. Meanwhile the people who are illiterate are called literate. In its development, literacy is used loosely and

\footnotetext{
${ }^{1}$ Keith R. Stamm and John E Bowes, The Mass Communication Process, A Behavioral and Social Perspective, in Nurudin, Pengantar Komunikasi Massa, (Jakarta: Raja Grafindo Persada, 2007), p.211
}

DOI: $10.9790 / 0837-2205056167 \quad$ www.iosrjournals.org $\quad 63 \mid$ Page


extensively not only in terms of literacy, but also related to other words of literary information so that it becomes the literacy of TV, and media.

\section{DISCUSSION}

In a social system, effectiveness is intended as the degree of how far the social system reaches its goal. Effectiveness is directly related to the achievement of a goal. In the relation to communication, the effectiveness of a communication means the success level of a communication produces commonness, understanding between the sources and the audience-receiver. A communication will be effective when the audience receives a message, understanding, and others just as the transmitterdesired.

In accordance with the interview with the Head of Communications and Informatics (KOMINFO)of North Sumatra on the relationship of effectiveness with LPP TVRI of NorthySunterraabout Mimbar Agama Islamin LPP TVRI, we broadcast it directly by cooperating with the Department of KOMINFO to broadcast the program so that its effectiveness can be felt by the people both in urban and rural. ${ }^{2}$

Meanwhile the interviewwith the Head of LPP TVRI of North Sumatra in the case of making Mimbar Agama Islamporgram. The program of Mimbar Agama Islamis in cooperation with KOMINFO of North Sumatra, then we will coordinate after preparation through discussion of both parties, then LPP TVRI makes the design of the program and broadcasts it directly. ${ }^{3}$

According to HasanSyadily in Ensiklopedia Indonesia, in terminology the effectiveness means showing the level of achieving a goal, an effort is said to be effective if the business reaches its goal.In order the effectiveness is according to the experts, the program of Mimbar Agama Islamdoes not only cooperate with KOMINFO but also must cooperate with other parties such as: MUI and community group in accordance with the result of interview of Head of KOMINFO.

The interviews results with the Department of KOMINFO of North Sumatera on the effectiveness of Mimbar Agama Islamat LPP TVRI. First: how to display the program as well as possible in accordance with the planning. Second: determinginthe day and time of the boradcasting, so as not to clash with other programs. With MUI we know that in the program there should be speakers, qori, and viewers who are present, here KOMINFO in cooperation with the MUI made the theme will be created. In terms of the funding there is some from the government of North Sumatra Province. ${ }^{4}$

Various studies revealed that television can have a direct impact on attitudes and behavior of the audience. James Monaco (1977), stresses the great ability of the television to connect the reality with the audience. The ability is due to the nature of television that presents the experiences on an ongoing basis, and not just one experience.The results of interviews with the Head of Public Sector if generally not, because the event can be conveyed to the public should the event in the design as attractive as possible so that the event is interesting, specifically has been adequate, because in the event of Islamic pulpit we create interactive, Enthusiastic community there.The making of a program, Mimbar Agama Islamabout the effectiveness here is needed various aspects of human resources (Human Resources), facilities and infrastructure and financial ability.

In Mimbar Agama Islamprogram cannot cooperate with other parties. Maybe you can, after you research in LPP TVRI, you will know the shortcomings and advantages, and maybe you can give input. Another example of private TV in the Mimbar Agama Islam programthey have made outside the studio not only in the studio, with the national informants, we are still a regional resource. ${ }^{5}$

The interviews results with the Head of Program Section, the problem of the budget, which must be adjusted when compared with the same private TV program, yes we certainly still lack, but do not forget, the only digital TV in North Sumatra is LPP TVRI SU. To better lead is actually a possibility due to noncommercial mission-mission, this is the obstacle. ${ }^{6}$ About Human Resources if the number is adequate but not enough in the proportional and professional, in making Mimbar Agama Islamprogram, a cameraman can also do the lighting arrangement and so on. ${ }^{7}$

According to Michael Eemery (1980), in Alimuddin, a more detailed review of the nature of mass media influence also reveals that media influence can be direct and indirect to the changing of knowledge,

\footnotetext{
${ }^{2}$ Interview with Drs.H.Mhd. Fitriyus, SH, M.SP, as the Head of the Department of KOMINFO of North Sumatra Province on Thursday 1 December 2016, at $09.30 \mathrm{~s} / \mathrm{d} 11.00 \mathrm{WIB}$.

${ }^{3}$ Interview with Zainuddin Latuconsina, SE, M.Si, as the Head of LPP TVRI of North Sumatera on Friday 2 December 2016 at $09.30 \mathrm{~s} / \mathrm{d} 11.00 \mathrm{WIB}$.

${ }^{4}$ Drs.H.Mhd. Fitriyus, SH, M.SP, ibid

${ }^{5}$ ibid

${ }^{6}$ Interview with Syahrani, as the Head of Program Division of LPP TVRI of North Sumatera on Wednesday on 7 Descmber 2016, at $13.30 \mathrm{~s} / \mathrm{d} 15.00 \mathrm{WIB}$.

${ }^{7} \mathrm{ibid}$ 
attitudes, and behavior of audiences. In certain conditions that affect it, it usually forms a number of factors that are not easily formulated because of the compound.Thus what television assumes as an important program to serve for viewers is not necessarily important for audiences. So the effectiveness of the content of the message depends on the situation and condition of the audience and its social environment. Based on that, the opinion of the pros and cons of the impact of television shows are: (1) television shows can threaten the social values in society; (2) the television programs can reinforce the social values in society; (3) the television programs will form new social values in people's lives.

According to the interviews with the Head of Finance Division on the effectiveness of Mimbar Agama Islam, LPP TVRI of North Sumatra in presenting a program especially the Mimbar Agama Islamcooperates with KOMINFO of North Sumatra, in funding this assistance by the governor with the funds is LPP TVRI broadcast, while the fund for the speakers, qori, and the host of this event is KOMINFO. ${ }^{8}$ When associated with the experts' opinions with the interviews about the effectiveness of the MimbarAgama Islamprogram, the broadcasting effects through television is achieved and the effect of mass media messages, messages delivered through the mass media to the viewers as a channel of information caused is the effect of knowledge and understanding of the audience, if In view of the cognitive effects of mass media is the television provides the communication about the MimbarAgama Islam program to the viewers.

The effect of effectiveness of the cognitive effect of the mass communication purposes in this case Mimbar Agama Islamthrough television is not just informing the audience about something but more than that, the audience is expected to share the feelings delivered. The effectiveness of a program in television mass media should have the effects of cognitive, affective, and behavioral.In the program of Mimbar Agama Islam it is expected to arise the behavioral effect that is as a result arises in the audience in the form of behavior, action or activity. The messages delivered by the mass media (television) continuously will greatly affect the behavior of the audiences.

\section{CONCLUSION}

The effectiveness of the Public Broadcasting Television's Mimbar Agama Islam of Republic of Indonesia of North Sumatera in improving the media literacy ability of the viewers in Medan City. The effect of television media can be interpreted as a difference that occurs in a person before and after receiving the information from the television, whether it occurs in the volume of knowledge, new attitudes, or new behavior.

Television as an electronic media that provides information, entertainment and attendance education can be accepted as a positive in order to display a wider cultural horizon, to enrich the science and technology and to play a role in educating the nation's life and shaping the Indonesian people as a whole. The choice of television programs determines the direction of positive or negative influence of the entire audience in general and the younger generation in particular. Therefore, it is necessary for a serious effort to educate the community (including students, teachers and parents) in order to receive selectively the mass media messages they receive. Therefore, the roles of experts from various disciplines (such as psychology, cultural, educational, legal) areneeded to select the television programs.

Production management is any effort/activity/process to achieve the goal effectively and efficiently. The management actions will relate to the decision-making on design and production control including all activities/processes to achieve a product in accordance with agreed objectives. The production management steps generally include: (a) designing products; (b) designing the manufacturing/production process; (c) designing Materials; (d) scheduling the manufacturing/production process; (e) dividing the work (f) submitting the job $(\mathrm{g})$ tracking the progress and $(\mathrm{h})$ revising the draft.

Using the principles and functions of Islamic communication such as (a) the information function, the convincing function, the reminding function, the motivating function, the socialization function, the guidance function, the spiritual satisfaction function, and the entertainment function. So that Mimbar Agama Islamprogram in LPP TVRI of North Sumatra can be a chosen program for the community.

\section{REFERENCES}

[1] Abdul Kadir Sayid Abd, Rauf, Dirasah Fid Dakwah al-Islamiyah, (Kairo: Dar El-Tiba'ah al-Mahdiyah, 1987

[2] Achlina, Leli dan Purnama Suwardi, Kamus Istilah Pertelevisian, Jakarta: Buku Kompas, 2011.

[3] Alibin Muhammad bin Ali al-Zain al-Syari Al-Jurjani, al-Ta'rifat, Beirut: Da al-Kutub al-Ilmiyyah, 14031983.

[4] Arifin, Psikologi Dakwah (Suatu Pengantar Studi), Jakarta: Bumi Aksara, 1994.

[5] Arifin, Eva, Broadcasting to be Broadcaster.edisipertama-Yogyakarta, GrahaIlmu, 2010.

\footnotetext{
${ }^{8}$ Interview with Bustami, SE, MM, as the Head of Finance Division of LPP TVRI of North Sumatera on Monday 5 December 2016 at 13.30 s/d 15.00 WIB. 
[6] Arikunto, Suharsimi, Prosedur Penelitian; Suatu Pendekatan Praktek, Jakarta: Rineka Cipta, 1991.

[7] Day, Mila, Buku Pinter Televisi, Jakarta: Trilogos Library, 2004.Depdikbud, Kamus Besar Bahasa Indonesia, Jakarta: Balai Pustaka, 1990.

[8] Departemen Pendidikan Nasional. Kamus Besar Bahasa Indonesia,Jakarta: Balai Pustaka, 2003, edisi ke-

[9] Depari, Eduard \& Colin Mac Andrew, Peranan Komunikasi Massa Dalam Pembangunan, Yogyakarta: Gajah Mada University Press, 1991.

[10] Devito, Josep A, Human Communication, dalam Nurudin, Pengantar Komunikasi Massa, Jakarta: Raja Grafindo Persada, 2007

[11] Elvinaro, dkk, Komunikasi Massa, Bandung: Simbiosa, 2004.Gerbner, George et. al. Living with Television dalam Stephen W. Littlejohn dan Karen A.Foss, Theories Of Human Communication, Thomson Wadsworth, $9^{\text {th }}$ Edition, 2008.

[12] Gordon, Scoot The History and Philosophy of Social Science, Bungin, Burhan, penerj. Konstruksi Sosial Media Massa, Jakarta: Kencana, 2011

[13] Hamid, Farid \& Hery Budianto, Ilmu Komunikasi: Sekarang dan Tantangan Masa Depan, Jakarta: Kencana, 2011.

[14] Hamzah, Publisistik Islam, Teknik Dakwah \& Leadership, h.47Hardiaman, MenujuMasyarakatkomunikatif, Jakarta: PT. Gramedia, 1993.

[15] Hefni, Harjani, Komunikasi Islam, (Jakarta: Prenadamedia Group, 2015)Herford, Peter, So You Want To Run a TV Station, dalamMorissan, JurnalistikTelevisiMutakhir, Bogor: Ghalia Indonesia, 2004.

[16] Hessel Nogi S. Tangkilisan, Manajemen Publik. Jakarta: PT. Grasindo, 2005.http://dewi.studentsblog.undip.ac.id/2009/05/27/perbedaan-efisiensi-dan-efektivitas/

[17] http://dakwah-belajar.blogspot.com/2013/03/22.11.27

[18] http://www.tempointeraktif.com/

[19] http://www.gustaf.web.id/2011/01/makalah-presentasi-pendagama.html (Di akses Tgl 24: 21.15)

[20] http://musyariaulia.blogspot.com/2011/03/sentuhan-sentuhan-tarbiyah-hakikat.html (Diakses 27-112011. 12:14)

[21] Katz, J. Blumler, and M.Gurevitch, Uses of Mass Communication by the Individual. New York; Preager, 1974.

[22] KebijakanPenyiaran(Editorial Policy) LPP TVRI, Jakarta: 17 Desember 2010.

[23] Kriyanto, Rachmat. TeknikPraktisRisetKomunikasi: DisertaiContohRiset Media, Publik Relation, Advertising, KomunikasiOrganisasi, KomunikasiPemasaran. Jakarta: Kencana. 2010.

[24] Kuntowijoyo, Paradigma Islam Interpretasi Untuk Aksi. Bandung, Mizan, 1993.

[25] Kuswandi, Wawan, Komunikasi Massa SebuahAnalisis Media Televisi, Jakarta: PT. RinekaCipta, 1996

[26] Koentjaraningrat.MetodePenelitianMasyarakat, Jakarta: PT Gramedia, 1991.

[27] Klapper, Joseph T., The Effect of Mass Communication, Glancoe, Ills Free Press, 1960.

[28] Mardalis. Metode Penelitian; Suatu Pendekatan Proposal, Jakarta: Bumi Aksara, 1995.

[29] Miles, Mathew B. and Huberman, Michael A,.Analisis Data Kualitatif(terjemahan: TjetjepRohendi) , Jakarta: UI Press, 1992.

[30] Muis, A., Komunikasi Islam, Bandung: PT. Remaja Rosdakarya, 2001.

[31] Mulyana, Dedi. Metodologi Penelitian Kualitatif, Paradigma Baru Ilmu Komunikasi dan Ilmu Sosial Lainnya, Bandung: Remaja Rosdakarya, 2004.

[32] Muhith, Koordinator Isi Siaran KPID Kepri, Dosen STIQ Kepri

[33] Muriah,Siti, Metodologi Dakwah Kontemporer, (Yogyakarta: Mitra Pustaka, 2000), h.32-34

[34] Morissan.TeoriKomunikasiIndividuHingga Massa, Cet.I, Jakarta: Prenada Media Group, 2013

[35] _ PeriklananKomunikasiPemasaranTerpadu, Jakarta: Prenadamedia Group, 2014

[36] __ Manajemen Media PenyiaranStrategiMengelola Radio danTelevisi, Jakarta: Kencana, 2008

[37] Mc Luhan, Marshall, Understanding Media, The Extension of Man, London: The MIT Press, 1999

[38] Nurudin, PengantarKomunikasi Massa, Jakarta: Raja Grafindo Persada,2007.

[39] Penjelasan UU R.I No. 32, Tahun 2002 tentang Penyiaran

[40] Pinckey,Triputra, Jurnal Penelitian Ilmu Komunikasi . "Dilema Industri Penyiaran diIndonesia" volume IV/No.1, Januari-April 2005

[41] Potter, James W, Media Literacy, dalam Elvianro, dkk, Komunikasi Massa, Bandung: Simbiosa, 2004.

[42] Postmant, Neil, Amusing Ourselves to Death:Public Discourse in the Age of Business, dalam Bungin, Burhan, , Konstruksi Sosial Media Massa, (Jakarta: Kencana, 2001

[43] Pringle, Peter, K., Michael F, Starr, William E. McCavitt, Electronic Media Management (Second Edition, Focal Press, Boston-London, 1991

[44] Quail, Denis, Mc, Teori Komunikasi Massa Suatu Pengantar, Jakarta: Erlangga, 1987

[45] Quail, Dennis, Mc., dan Steven Windhal., Communication Models for Study of Mass Communication. London: Longman, 1979. 
[46] _. Communication Model for The Study of Mass Communication. Belmont California, Wadsworth Publishing Company, 1988.

[47] Rahmad, Jalaluddin, Psikologi Komunikasi, Bandung Remaja Rosdakarya, 2003.

[48] Salim, Peter. Kamus Besar Bahasa Indonesia Kontemporer. Jakarta: Modern English Press, 1991, Cet.ke-

[49] Sasono, Adi, Didin Haiduddin, Saefudin, dkk, Solusi Islam Atas Problematika Ummat(EkonomiPendidikan dan Dakwah), Jakarta:Gema Insani, 1998

[50] Saydam, Gouzali, Teknologi Telekomunikasi, Bandung: CV. Alfabeta, 2005.Sendjaya, Sasa Djuarsa. Teori Komunikasi, Jakarta: UT, 2002.

[51] Silverblatt, Art, Media Literacy: Keys to Interpreting Media Messages, London: Praeger, 1995.

[52] Shihab, Quraish, M Tafsir Al-Mishbah Jilid.2, Jakarta: Lentera Hati, 2000

[53] Syukir, Asmuni, Dasar-dasar Strategi Dakwah Islam, Surabaya: Al- Ikhlas, 1983Sunanal-Tirmidzi, juz 4, h. 43, hadis No. 2178

[54] Suprapto, Tommy. Pengantar Teori \& Manajemen Komunikasi. Yogyakarta: Medpress, 2009.

[55] Spradley, TeknikAnalisis Data Model Spradley. 2010. [Tersedia Online] http:// banets.blogspot.com/2010/08/analisis model spradley.html, di akses April 2015.

[56] Stamm, Keith R. dan John E. Bowes, The Mass Communication Process, A Behavioral and Social Perspective, dalam Nurudin, penerj. Pengantar Komunikasi Massa, Jakarta: Raja Grafindo Persada, 2007.

[57] Stoddard, L., The Rising Tide of Color, (Pasang Naik Kulit Berwarna), Jakarta: Panitia Penerbit, 1966

[58] Syadily, Hasan. Ensiklopedi Indonesia. Jakarta: Ichtiar Baruvan Hocve, jilid 2.

[59] Syabibi, Ridho, Metodologi Ilmu Da'wah, Yogyakarta: Pustaka Pelajar, 2008

[60] Tamburaka, Apriadi, Agenda Setting Media Massa, Jakarta: PT. Raja Grafindo Persada, 2013.

[61] Tasmara, Toto, Komunikasi Dakwah, (Jakarta: Gaya Media Pratama, 1997), h.43

[62] Terry, George R., Prinsip-Prinsip Manajemen. (edisi bahasa Indonesia), Bandung: PT. Bumi Aksara, 2010.

[63] Tim Redaksi LP3ES. Jurnalisme: Antara Peristiwa dan Ruang Publik. Jakarta: Pustaka LP3ES, 2006.

[64] Tim Penulis, M. Arifin, Ilmu Pendidikan Islam,(Jakarta: Bumi Aksara, 1991

[65] Tobing, Sumita, DirutPerjan TVRI, dalam Seminar TuntunanProfessionalismeTelevisi, Jakarta: November 2001

[66] Thanthawi, Muhammad Sayyid, Etika Dialog Dalam Islam, Jakarta: Mustaqhm, 2004

[67] Usman, Husaini, Manajemen: Teori, Praktik, dan Riset Pendidikan, Jakarta: Bumi Aksara, 2012.

[68] Unde, AlimuddinAndi, Televisi\&MasyarakatPluralistik, Jakarta: Prenadamedia Group, 2014.

[69] Vane, Edwin T.. Lynne S. Gross: Programming for TV, Radio and cable, dalam Morrison, Manajemen Media PenyiaranStrategiMengelola Radio danTelevisi, Jakarta: Kencana, 2008.

[70] Wahyudi, J.B., TeknologiInformasidanProduksi Citra Bergerak, Jakarta: GramediaPustakaUtama, 1992. 